\title{
Ana Akım İktisat ve Kapitalizm İlişkisi: Eleştirel Bir Giriş
}

\section{The Relationship between Mainstream Economics and Capitalism: A Critical Introduction}

\author{
Adem Levent a,* \\ ${ }^{a}$ Dr. Öğr. Üyesi, Bursa Uludağ Üniversitesi, İktisadi ve İdari Bilimler Fakültesi, İktisat Bölümü, 16240, Bursa/Türkiye. \\ ORCID: 0000-0002-1683-6107
}

\begin{tabular}{l} 
MAKALE BİLGİSİ \\
\hline Makale Geçmişi: \\
Başvuru tarihi: 21 Aralık 2019 \\
Düzeltme tarihi: 03 Ocak 2020 \\
Kabul tarihi: 13 Ocak 2020 \\
\hline Anahtar Kelimeler: \\
Anaakım İktisat \\
İktisat Sosyolojisi \\
Politik Felsefe \\
Sosyal Teori \\
Kapitalizm
\end{tabular}

\section{A R T I C L E IN F O}

\section{Article history:}

Received 21 December 2019

Received in revised form 03 January 2020

Accepted 13 January 2020

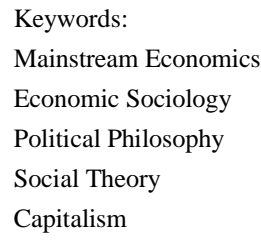

Keywords:

Mainstream Economics

Economic Sociology

Political Philosophy

Social Theory

Capitalism

ÖZ

Modernliğin genel bilimi olarak öne çıkan politik iktisat, herhangi bir disipliner sınırlamaya tabi olmadan kurumlar, sınıf, hukuk, politika ve ekonomi gibi geniş bir inceleme alanına sahiptir. Politik iktisat, ticari ve sanayi kapitalizmi dönemlerinde geliştiği için kendini var eden toplumsal gerçekliği bir bütün olarak analiz etmeye çabalamıştır. Ancak 19. yüzyılın sonlarında fiyatlama sorununu çözmek için fayda değer kavramının öne çıkması ve sosyal bilimler arasında gerçekleşen entelektüel işbölümü kapsamında politik iktisat, iktisada dönüşürken araştırma nesnesini daraltmıştır. Bunun sonucu iktisat bilimi, kapitalizmi araştırma nesnesi olmaktan çıkararak piyasa dengesi, tüketici faydas1, bireysel kâr maksimizasyonu gibi disiplin içi teknik meseleleri temel araştırma nesnesi olarak kabul edip bilimsel faaliyetlerine devam etmektedir. Bu nedenle bu çalışmada günümüz iktisat biliminin, teknik bir boyutta ilerlediği için gündelik yaşamımızı doğrudan etkileyen kapitalist sistemi analiz edemediği iddia edilmektedir.

\section{Giriş}

Batı düşüncesinin tarihsel gelişim süreci içinde ortaya çıkan ve ekonomik olduğu kadar politik ve sosyal bir sistem de olan kapitalizm, ana akım iktisat bilimi açısından nasıl anlaşılıp yorumlanmaktadır? Sanayi kapitalizminin doğrudan sonucu olarak gelişen iktisat bilimi, kendini var eden ilgili kapitalist toplumsal gerçekliği ve onun gelişim sürecini nasıl analiz etmektedir? Ya da nomotetik bir sosyal bilim kabul edilen iktisat, kapitalizmi temel araştırma nesnesi olarak analiz etmekte midir?

Söz konusu soruları genelde sosyal bilimler özelde de ana akım iktisat bilimi ve kapitalizm ilişkisi bağlamında cevaplamanın iki açıdan önem arz ettiği söylenebilir. Birincisi, içinde yaşadığımız dünyayı anlamak ve yorumlamak için ekonomik, politik ve sosyal olduğu kadar gündelik yaşamımızı da doğrudan etkileyen ve hatta son

\footnotetext{
* Sorumlu yazar/Corresponding author e-posta: levent49@gmail.com
} 
y1llarda insan varlığına yönelik biyolojik müdahalelerde de bulunan bir sistem olan kapitalizmi tahlil etmek mühimdir. Çünkü günümüzde neredeyse yaşadığımız her "kötülüğün" kaynağı kapitalizme ait görülerek kapitalist sistem ciddi şekilde eleştirilmekte ve mahkûm edilmektedir. Ancak bu eleştiriler karanlığa söylenmiş sözler gibi ciddi bir temelden yoksun şekilde giderek boşlukta yok olmaktadır. İlgili eleştiriler kapitalizmi sınırlı sonuçlar üzerinden değerlendirdikleri için bizzat kapitalizmin anlaşılmasını da engellemektedir. ${ }^{1}$ Ayrıca kapitalizmi sadece "iktisadi eşitsizlikler" üzerinden yorumlamak da aynı şekilde bu çok yönlü sistemi anlamaktan uzak bir yaklaşımla meselenin ele alındığını göstermektedir. Bu nedenle kapitalist sistemi sınırlı sonuçlar ve belirli değişkenler üzerinden değil, bir bütün olarak analiz etmek gerekir. İkincisi ise, günümüzde sosyal bilimler ile yaşadığımız kapitalist toplumsal gerçeklik arasında bir anlam bağı kurmamız önemlidir. Sosyal bilimler modern dönemde Sanayi Devrimi sonrası kapitalist gerçekliği anlamak ve yorumlamak üzere ortaya çıktıklarına göre, bu bağ kaçınılmaz şekilde kurulmaktadır. Ancak sosyal bilimlerin gelişim seyrine daha yakından baktığımızda bu bağın güçlü bir şekilde kurul(a)madığını, sosyal bilimlerin kendi araştırma nesnelerini dar bir çerçevede belirginleştirdikleri ve kapalı devre çalışan sınırlı akademik söylemler ürettikleri görülmektedir.

Sosyal bilimler içinde sınırlı akademik söylemlerin oluşum evresini 19. yüzyıla götürmek mümkündür. 19. yüzyılın sonlarında başlıca üç nomotetik sosyal bilim arasında şu şekilde bir entelektüel işbölümü gerçekleştiği söylenebilir: "İktisadi alan" veya "piyasa" kavramı iktisat biliminin, "politik alan" veya "iktidar" kavramı politik bilimin, "sosyal alan" veya "sosyal yapı" kavramı da sosyoloji biliminin araştırma nesnesi olarak belirginleştiğinden her üç akademik disiplin de kendi içlerinde paradigmatik bir dil geliştirmiştir. Nomotetik sosyal bilimciler kendilerine ait disiplinin diğer disiplinlerden hem tema hem de metodoloji yönünden farklı olduğunu göstermeye girişmişlerdir. İktisatçılar, piyasa mekanizmasını inceleyebilmek için diğer koşullar sabitken (ceteris paribus) varsayımını vurgularken politik bilimciler ilgi alanlarını resmi hükümet yapılarıyla sınırlandırmışlardır. Sosyologlar ise iktisatçıların ve politik bilimcilerin önemsemediği sosyal ilişkileri öne çıkarmışlardır. 1945 sonrasına gelindiğinde disipliner ayrışmalar kesinleşmiş ve sosyal bilim disiplinlerinin hemen hepsi, dünyanın belli başlı üniversitelerinde büsbütün kurumsallaşmıştır (Gulbenkian Komisyonu, 2003: 36).

\footnotetext{
1 Kapitalizmin sınırlı sonuçlar üzerinden analiz edilmesine “mülkiyet temelli özcülük" örnek verilebilir. Mülkiyet temelli özcülük kapitalizmi sadece üretim araçlarının mülkiyet ilişkilerine indirgeyerek tahlil eder (Block, 2019: 1167). Hiç şüphesiz bu analiz kapitalist toplumsal ilişkileri anlamak için önemlidir ancak bunun bir yönüyle "ekonomizm" içerdiği unutulmamalıdır.

${ }^{2}$ Sadece iktisat biliminin değil, neredeyse bütün sosyal bilimlerin aşırı uzmanlaşmasının sonucu olarak kapitalizmin doğası veya Keynesçilik gibi "büyük meseleleri" inceleme nesnesi olmaktan çıkardıklarına ilişkin bkz. Block (2019).

${ }^{3}$ Abba Lerner'e göre (1972: 259) iktisadi işlem çözülmüş politik problemdir. İktisat, politik problemlerini çözüp egemenlik alanını genişleterek sosyal bilimlerin kraliçesi olmuştur. Yani iktisat herhangi bir șekilde tartışmaya mahal vermeyecek bir kesinlik fikriyle bilimsel yolculuğuna devam ederken "politik" olanı dışlamıştır. Buradaki politik olan daha spekülatif karakterli bir
}

Söz konusu entelektüel işbölümü çerçevesinde bu çalıșma, iktisat özelinde kapitalist toplumsal gerçeklik ile ana akım iktisat bilimi arasında bir ilişkinin varlığını sorgulamayı hedeflemektedir. Bu hedef doğrultusunda çalışma boyunca "Ana akım iktisat bilimi kapitalizmi analiz edebilir mi?" sorusu cevaplanmaya çalıșılacaktır. İlk bakıșta bu soru anlamsız ve ironik gelebilir. Çünkü yaygın kanı, iktisadın kapitalizmin bilimi olduğunu varsayarken iktisatçıların da diğer sosyal bilimcilere nazaran kapitalizmi en iyi anlayan ve çözümleyen "bilim insanları" olduğuna yöneliktir. Ancak ana akım iktisat biliminin gelişim sürecine ve mevcut konumuna daha yakından bakıldığında söz konusu soru anlam kazanmaktadır. Mevcut ana akım iktisat bilimi ve öğretimi, teknik bir boyutta ilerlediği için gündelik yaşamımızı doğrudan etkileyen kapitalist sistem hakkında çözümleme yapamamaktadır. ${ }^{2}$ Hatta daha da vahimi yapamadığının farkında da değildir ve bunu bir eksiklik olarak da görmemektedir. Benimsediği bilimsel kesinlik formunu ileri boyutlara taşıyarak sosyal bilimlerin ortaya çıktığ1 süreçte gerçekleşen entelektüel iş bölümü kapsamında kendine düşen rolü fazlasıyla yerine getirmektedir. Ana akım iktisat bilimi içe kapalı ve kendinden emin iç yolculuğuyla teknik analizde güçlenirken diğer sosyal bilimlerden uzaklaşarak onların araştırma çabalarını "spekülatif" addetmektedir. ${ }^{3}$ Bu nedenle ana akım iktisat bilimi ve kapitalizm ilişkisi günümüz akademik kategorizasyonunda iktisat bilimine yön veren ana akım iktisatçılar tarafından iktisat dişı veya sosyal teoriye ait bir konu olarak görülmektedir. Dolayısıyla ana akım iktisat bilimi, günümüzde, kapitalizmi araştırma nesnesi olmaktan çıkararak piyasa dengesi, tüketici faydası, bireysel kâr maksimizasyonu gibi disiplin içi teknik meseleleri temel araştırma nesnesi olarak kabul edip yoluna devam etmektedir. $^{4}$

Tabi bu çalışmada ana akım iktisadi teorinin kapitalizm analizi yapamadığı iddia edilmektedir. Kurumsal iktisat ve Marksist/radikal politik iktisat gibi heterodoks iktisat okulları ise ana akım iktisat tarzında teknik bir kavrayıșa sahip olmadıkları için hem kapitalizmi araştırmalarının temel sorunsalı yapmaktalar hem de diğer sosyal bilimlerle ilişkili bir akıl yürütmeye sahip olduklarından içinde yaşadığımız kapitalist düzene yönelik anlama çabaları göstermektedirler. Ancak bu okulların da içinde yaşadığımız kapitalist toplumsal gerçekliği tam olarak ele aldıklarını söylemek mümkün değildir. $\mathrm{Bu}$ okulların da sınırlı kavramlar ve bilimsel söylemler üzerinden kapitalist

bilgiye gönderme yapmaktadır. Ona göre iktisat, spekülatif karakterli bilgiden yani felsefeden uzaklaştığı müddetçe saygın bir bilim olabilir. Bu durum, ana akım iktisatçılar için bir övünç kaynağıdır.

${ }^{4}$ Kuşkusuz 1980 sonrasında yeni kurumsal iktisat, evrim teorisi, oyun teorisi gibi yeni yaklaşımlar yardımıyla ana akım iktisadın araştırma nesneleri genişlemeye başlıyor. Böylece ana akım iktisat klasik araștırma konularının ötesine uzanarak bir taraftan bilimsel olarak daha da güçlenip kendinden emin bir konum elde ederken diğer taraftan bu güçlü konumun etkisiyle kapitalizm analizinden daha da uzaklaşıyor. Çünkü bilimsellik kriterlerini yerine getirerek doğru adımlarla yürüdüğünü kanıtlıyor ve sosyal teoriye ait bir konu olarak kabul ettiği kapitalizmi "yüksek standartlardaki bilimsel etkiliğine" dahil etmiyor. İktisattaki son gelişmelerin disiplinin ufkunu ne yöne doğru götürdüğüne ilișkin ayrıca bkz. Davis (2008); Frey ve Benz (2004). 
toplumsal gerçekliği kavradıklarından kapitalizme dair bütünlüklü bir sosyal teori geliştirdiklerini söylemek güçtür. Gerçi Geoffrey M. Hodgson (1996; 2015) ana akım neoklasik iktisat, kurumsal iktisat, Marksist iktisat ve Avusturya iktisat okulu gibi çeşitli iktisat teorilerinden sadece kurumsal iktisadın aktör ve yapı ilişkisi analiziyle kapitalizmin çeşitlerine, kültürüne ve geleceğine yönelik daha olgun bir tarzda kapitalizm analizi sunduğunu iddia etmektedir. Benzer şekilde Stjepan Mestrovic (2004: 13) kurumsal iktisadın öncüsü Thorstein Veblen'in Karl Marx'a göre daha olgun ve üstün bir analize sahip olduğunu belirtir.

$\mathrm{Bu}$ bağlamda "Ana akım iktisat bilimi kapitalizmi analiz edebilir mi?" sorusunun (olumlu veya olumsuz) cevaplanması hem içinde yaşadığımız kapitalist toplumsal gerçekliği anlamak hem de iktisat özelinde çağdaş sosyal bilimlerin entelektüel müktesebatlarının ne oranda günümüz dünyasında yaşanan maddi gerçekliği açıklayabileceğini çözümlemek için önem arz etmektedir. Bu nedenle bu çalışmada ana akım iktisat biliminin teorik araçlarıyla kapitalizmi analiz etmenin mümkün olup olmadığı tartışılacaktır. Bu amaçla çalışmada ilkin modern kapitalizm ve sosyal bilimler ilişkisi incelenecek ardından ana akım iktisat biliminin bugünkü konumu bir teknikleşme süreci olarak ele alınacaktır. İlgili kısımda çalışmanın temel iddiası olan, ana akım iktisat biliminin kapitalizmi niçin analiz edemediği açıklanacaktır. Devamında ise modern sosyal teorinin önemli bir kısmını oluşturan iktisat sosyolojisi ve modern kapitalizm ilişkisi incelenecektir. Son olarak günümüz kapitalizmini anlamak için politik iktisat bağlamında politik felsefe ve sosyal teorinin imkânları sorgulanacaktır.

\section{Sosyal Bilimler ve Modern Kapitalizm}

Sosyal bilimlerin doğası ve gelişimi üzerine düşünmeye başlamak ister istemez modern kapitalizmin doğası üzerine düşünmeyi de gerektirir. Çünkü sosyal bilimlerin ortaya çıkış süreci ile kapitalizmin doğuşu arasında sıkı bir irtibat bulunmaktadır. Özellikle mali ve ticari kapitalizm dönemlerinde tam olarak ortaya çıkmayan ama bilimsel alt yapısı hazırlanan sosyal bilimler, sanayi kapitalizmiyle varlık göstermişlerdir.

Sanayi kapitalizmi sonrası ortaya çıkan sosyal bilimlerin iki görevinin olduğu söylenebilir. Birinci görev, sanayi kapitalizmiyle ortaya çıkan yeni toplumsal yapının analizidir. İkinci görev ise, bu yeni yapının toplumsal hayatta doğurduğu gerilimleri ortaya koyarak bunları eleştirel bir analize tabi tutmaktır. Sosyal bilimlerin birinci görevi yeni toplumsal yapının hem açıklamasını hem de onun örtük olarak meşrulaştırılmasını yapar. İkinci görev ise söz konusu meşrulaştırmayla beraber yeni toplumsal yapının doğurduğu sorunları çözmeyi esas alır. Neredeyse bütün sosyal bilimlerde bu iki görevin gerilimli ilişkisini görmek mümkündür. $\mathrm{Bu}$ gerilim bazen felsefi düzlemde, doğa bilimleri ve sosyal bilimlerin doğaları hakkında bir metot tartışması şeklinde kendini gösterirken, bazen de bizzat disiplin içi bir tartışma kimliğine bürünebilmektedir (Y1lmaz, 2018: 12).

Sosyal bilimlerin gelişimi ve kapitalizm arasındaki ilişki Immanuel Wallerstein tarafından da ortaya konmaktadır. Wallerstein'a göre (2000: 153-156) bilim dünyasındaki genel kabul, dünyaya ilişkin daha doğru bir kavrayışa rasyonalite kavramı ile ulaşılması yönündedir. Rasyonalite ile kapitalizm sonrası gerçek toplumun daha iyi yönetilmesine ve insan potansiyelinin daha fazla gerçekleşmesine doğru da adım atılmış olunmaktadır. Bilgi inşa etme tarzı olarak sosyal bilim söz konusu öncül üzerine kurulmuş ve kendini ilgili rasyonel arayışın en güvenilir metodu olarak sunmuştur. $\mathrm{Bu}$ bağlamda kapitalizmin yükselişi ile bilim ve teknolojinin gelişimi arasında bir bağ olduğu gözlemlenmektedir. Teknolojinin gelişimi ve merkezi hale gelmesi için önce kapitalizmin ortaya çıkması gerekir. Bunun aksi mümkün değildir. $\mathrm{Bu}$ durum, iktidar ilişkilerinin gerçekliklerine uymaktadır. Yani modern bilim kapitalizmin evladıdır ve ona bağımlı olarak gelişmiştir. $\mathrm{Bu}$ nedenle bilim insanları toplumsal onay ve destek görmüşlerdir. Çünkü bilim insanları gerçek dünyada somut ilerlemeler sunmuşlardır. İnsan üretkenliğini artıracak ve zamanla mekânın dayattığı sınırlamaları azaltıp herkes için daha büyük bir rahatlık yaratacak makinalar bilim insanları aracılığıyla oluşmuştur. Kısacası bilim işe yaramıştır (Wallerstein, 2000).

İşe yarayan bilim, kapitalizmin nasıl ortaya çıktığı ve nasıl geliştiği üzerine yoğunlaşmıştır. 19. yüzyılın sonlarında sosyal bilimlerin temel meselesi "Kapitalizm niçin Çin'de çıkmadı?" sorusudur. Max Weber'in bu sorusu birçok tarihçiyi ilgili konu etrafında toplamıştır. Weber'e göre 1200'lü yıllarda yabancı ziyaretçiler Çin'e ayak bastıklarında Çin "medeni”, Batı Avrupa "barbar" olarak görülüyordu. Ancak 1890’da yabancılar benzer bir ziyaret yaptıklarında bu defa Çin "geri kalmış", Batı Avrupa gelişmiş bir medeniyet olarak görülüyordu. Pekiyi yaklaşık 700 y1llık bu dönemde ne olmuştu? 1200-1900 y1lları arasında Avrupa ve Çin arasında gerçekleşen farklılaşmaya ilişkin büyük rraksama açıklamaları sunuldu. Çin yabancı etkisi korkusuyla içe kapandı ve yabancılarla ticareti kısıtladı. Ayrıca kapitalizmin yükselişine karşı diğer faktörler de devreye girdi, böylece Çin "geri kaldı". Weber, Batı Avrupa'da kapitalizmin gelişimine dair "Protestan ahlakının" etkisiyle beraber hukuk, politika ve coğrafyanın kültür ve iktisadi politikayla karışmasıyla etkili bir açıklama getirdi. Kısacası 19. yüzyılın sonunda dünya manzarası ikiye bölünmüştü: Bir tarafta Batılı kapitalist dünya diğer tarafta kapitalist olmayan "az gelişmiş" dünya. Batı Avrupa yaklaşık 700 yıllık bir dönemi bilimsel bir akıl ve piyasa önceliğinde bir yol kat ederek kapitalistleşmişti (Boettke vd., 2005: 283).

Söz konusu kapitalistleşme bağlamında sosyal bilimlerin yukarıda ifade edilen ilk görevini iktisat özelinde gözlemlemek mümkündür. Sanayi kapitalizmi sonrası iktisadi faaliyetler sermaye bağlamında örgütlenmeye başlamıştır. $\mathrm{Bu}$ nedenle sanayi kapitalizmi sonrası iktisat bilimi, 18. ve 19. yüzyıllarda geliştirilmiş entelektüel bir projedir. 20. yüzyılda ise akademik olarak iktisadın özerk bir disiplin ve doğa bilimlerine en yakın sosyal bilim olduğu yaygın olarak kabul edilmiştir (Özel, 1994: 7). Doğa bilimlerine en yakın sosyal bilim olarak iktisat, teorik araçlarıyla kendisini var eden kapitalist toplumsal gerçekliği acaba analiz edebilmekte midir?

\section{Ana Akım İktisat ve Modern Kapitalizm}


Bugün sadece iktisat bilimi (economics) olarak bilinen sosyal disiplin, 17. yüzyıl başlarından 19. yüzyılın sonlarına kadar politik iktisat (political economy) olarak adlandırılmaktadır. $\mathrm{Bu}$ dönemde politik iktisat, politik felsefe ve sosyal teori işlevi görmekte ve modernliğin genel bilimi olarak kabul edilmektedir. Politik iktisat, gelmekte olan kapitalist toplumsal yapıyı çok yönlü bir şekilde izah etmeye çalışmaktadır. Politik iktisat olarak gelişen çabalar, bir taraftan İskoç Aydınlanmasının felsefi mirasını (Dow vd., 1997; Omori, 2003) taşırken diğer yandan da Sanayi Devrimi sonrası gündelik yaşamdaki değişimleri ve doğal hukuk ile doğal düzen arasındaki ilişkileri (Cardoso, 2004) anlamaya koyulmaktadir. ${ }^{5}$

Ancak politik iktisat, zamanla tarihten ve sosyal olandan uzaklaşarak "karamsar (dismal) bir bilim" olarak iktisada dönüşmüştür. $\mathrm{Bu}$ dönüşümde metodolojik olarak iki bölünmenin büyük payı vardır. Birinci bölünme, soyut (tümdengelimsel) ile tarihsel (tümevarımsal) yöntemler arasındaki ikiliğin ortaya çıkmasıdır. Bu bölünmenin klasik politik iktisatçılar David Ricardo ve Thomas R. Malthus'tan başlayıp İkinci Dünya Savaşı'na kadar uzanan bir tarihi vardır. Söz konusu metodolojik ayrışmanın doruğa çıktığı nokta ise Avusturya iktisat okulu kurucusu Carl Menger ile Alman tarihçi okulu öncüsü Gustav Schmoller arasında yaşanan yöntem kavgasıdır (Methodenstreit). İkinci bölünme, klasik politik iktisattan neoklasik iktisada geçişte, marjinalist devrim yoluyla disiplinin özünde ve metodolojisinde gerçekleşen içerik dönüşümüdür. $\mathrm{Bu}$ iki dönüşüm öncesi çoğu klasik politik iktisat yazarı, özellikle de Adam Smith ve John Stuart Mill için politik iktisat sadece basit bir iktisat değil, bütünleşik bir sosyal bilim olarak anlaşılmaktadır (Milonakis ve Fine, 2009: 1). Ancak söz konusu dönüşümler sonrası iktisat, şeyler arasındaki ilişkileri inceleyen tarih dışı ve evrensel bir karakter kazanmıştır. Benimsediği metodoloji ise aksiyomatik matematiktir.

19. yüzyılın sonlarında başlayan politik iktisadın iktisada dönüşüm süreci, 1950'li yıllarda Chigaco'da genel denge teorisinin sistematize edilmesi ve ekonometrinin gelişimiyle hem neoklasik iktisadın popülerleşmesi hem de ana akım iktisadın kurulmasıyla desteklenmiştir. Popülerleşmeden kasıt, disiplin içinde ve dışında akademisyenlerin disiplinin doğasının tanımlanmasına ilişkin konsensüse varmalarıdır. 1930'lu yıllarda London School of Economics (LSE)'de iktisadın tanımlamasına ilişkin gelişen Lionel Robbins ve Friedrich A. Hayek işbirliğinin 1950'lilerde Chigaco'da Frank Knight ve Hayek işbirliğiyle devam etmesidir. Robbins, marjinalizmden devraldığ genel denge vizyonunu düzenleyerek iktisadı bir seçim bilimi olarak tasarlamıștır. Devamında Paul Samuelson'ın ekonomik analiz temellerini fizikten başlatması ve Milton Friedman'ın pozitif metodoloji katkılarıyla neoklasik iktisadın analiz sütunları kurulmuştur. Sonucunda genel denge teorisi ve ekonometri ana akım

\footnotetext{
${ }^{5}$ Jean Jacques Rousseau (2005: 7), iktisadı (oikonomi) ev işlerinin akla ve belli kuralara uygun biçimde çekilip çevrilmesi anlamında kullanırken politik iktisadı, en büyük ailenin yani devletin yönetimini de kapsayacak biçimde genişleterek kullanır.

${ }^{6}$ İktisatta ana akım, ortodoks ve heterodoks ayrımlarının disiplin içi egemenlik mücadelelerine, kullanımlarına ve bunlar arasındaki ilişkilere yönelik bkz. Bögenhold (2010); Colander vd. (2004); Dequech (2007/2008).
}

iktisadın alet kutuları olmuștur (Becchio ve Leghissa, 2017: 90).

Neredeyse bütün sosyal bilimlerde iktisadın araştırma nesnesi söz konusu şekilde kabul edilirken bunun sonucunda, bir taraftan neoklasik iktisat ana akım iktisat olmakta diğer taraftan da iktisat bilimi giderek teknikleşmektedir. Başka bir deyişle iktisat biliminin teknikleşme süreci aynı zamanda ana akım iktisadın gelişim sürecini belirtmektedir. ${ }^{6}$ Ve bugün neoklasik iktisat ana akım iktisattır. Neoklasik iktisat, kökleri marjinalizme dayanan ve İkinci Dünya Savaşı sonrası büyük oranda kurumsallaşmasını tamamlayan iktisat öğretisidir. Neoklasik iktisat ifadesi, ilk kez 1900 yılında Thorstein Veblen tarafından kullanılmış ve ardından marjinalizmin Marshallyan versiyonunu karakterize etmek için sonraki iktisatçılar tarafından kabul edilmiştir. Veblen için neoklasik iktisat, merkezinde Alfred Marshall'ın olduğu faydacı ve hedonist psikoloji varsayımlarına dayanan bir yaklaşımdır (Aspromourgos, 1986: 265-266). Ana akım neoklasik iktisadın rasyonalite, genel denge ve kişisel çıkara dayalı faydasını maksimize eden bireysel davranış olmak üzere üç temel özelliği bulunmaktadır. İlgili teori, statik bağlamda tamamen rasyonel ve kusursuz bir bilgiye sahip bireylerin optimize edici davranışlarına ve bu optimizasyon sonucu oluşan genel dengeye dayalı analize odaklanır. Ana akım neoklasik iktisat, marjinalizm ve sonrasındaki gelişmelerle kurumsallaşır. Bu nedenle Leon Walras ve Alfred Marshall neoklasik teorinin erken ve önemli teorisyenleri şeklinde anılırken, John Hicks'in Değer ve Sermaye adlı eseri ile Paul Samuelson' In Iktisadi Analizin Temelleri adlı eseri neoklasik teorinin zirvesi olarak kabul edilir (Colander vd., 2004: 490). İlgili gelişmeler sonrası ana akım iktisatçılar iktisadı tanımlarken genelde neoklasik iktisat terimini kullanmazlar. Onlar daha çok "neoklasik büyüme teorisi” veya "neoklasik sentez" gibi ifadeleri kullanırlar (Colander, 2000: 132). Nedeni ise ana akım iktisatçılara göre iktisadı tanımlarken böyle bir ön ekin kullanımına gerek yoktur. Çünkü neoklasik teori hâkim ve geçerli teoriyi ifade ettiği için iktisadın bizzat kendisidir. ${ }^{7} \mathrm{Bu}$ teori dışında yapılan bilim faaliyetleri iktisada ait görülmez. Ana akım neoklasik iktisat dışındaki iktisadi faaliyetler olsa olsa "sosyal teoridir".

Bu bakımdan 1940 ve 1990 arasında bir disiplin olarak iktisat büyük bir dönüşüm geçirmiştir. Disiplin teknik bir bilime dönüşmüş ve disiplinin çekim merkezi İngiltere'den Amerika'ya kaymıştır. ${ }^{8}$ Matematiksel analitik tekniklerin "erdemi" disiplin içinde büyük kabul görmüştür. Bu dönüşüm formalizm (matematikleşme) olarak değerlendirilmiştir. Bununla iktisat, gündelik yaşama dokunuşunu kaybetmiş, sosyal meselelere ilgisiz kalarak daha formel ve matematiksel bir görünüme kavuşmuştur. Formalist iktisat, bireysel iktisadi aktörlerin davranışları hakkında küçük sayısal varsayımlarla başlamış ancak giderek iktisat disiplininin bütün ufkunu kaplamıştır (Solow,

71980 sonrası yeni araştırma programlarının iktisada dâhil olmasının neoklasik iktisadın egemen konumunu sarsmadığına ilişkin bkz. Dow (2008).

8 İkinci Dünya Savaşı sonrası disiplinin merkezinin Avrupa'dan Amerika'ya kayması ve bu durumun oluşmasında göçmen iktisatçıların payına ilişkin bkz. Hagemann (2011). 
1997: 42). Böylece iktisat, soyut ve evrensel bir bireysel aktör tasarlayip genel olan ancak tarihsel olmayan "gerçekler" türeterek bilim yapmayı sürdürmüştür. Başka bir deyişle evrensel geçerlilik iddiası olan ancak tarihsel yönü bulunmayan fayda, kıtlık, seçim ve denge gibi kavramları matematiksel araçlarla ifade edip bilimsel "kesinlik" söylemini ilerletmiştir. Fakat bunun sonucunda sosyoekonomik sistemin temellerini çözümlemekten uzaklaşmıştır. Yani bu durum kapitalizm veya diğer sosyoekonomik sistemleri anlamanın önünde bir bariyer oluşturmuştur. Ana akım neoklasik iktisat, ticari ve ticari olmayan ilişkileri birbirinden ayırmada başarısız olurken gerçek piyasaların sınırlarını, doğasını ve piyasaların işlem maliyetlerini çözümlemede de körleşmiștir. Çünkü kapitalist sistem ve onun özgül (muayyen) özelliği, soyut ve genel kavramlardan ziyade katışılılık/saf olmama (impurity) ilkesi bağlamında çözümlenmelidir. $\mathrm{Bu}$ ilke, kapitalist sistemde piyasaya ait olan (iktisadi) ile piyasaya ait olmayan (iktisadi olmayan) arasındaki sınırın tam olarak belirginleşmemesi üzerine kuruludur. ${ }^{9}$ Bugün kapitalizm aile, hane halkı üretimi ve devletin katışıklılıklarına bağlıdır. Katışıklılık, alt sistemlerin farklı türlerinin bir bütün olarak sistemin işlemesi ve sistemin var olması için kaçınılmaz konumda görüldüğü ilkedir. Kapitalizmin bir sistem olarak var olabilmesi, alt sistemlerin çeşitli türlerinin birleşmesini zorunlu kılmaktadır. Bu ilke fonksiyonalizm de değildir. Ana akım neoklasik iktisat, pür soyut ve tarihsel olmayan kavramlarla bilimsel söylem ürettiği için kapitalizmi ve dayandığı katışıklılık ilkesinden oluşan kapitalizmin türlerini çözümleyememektedir (Hodgson, 1996).

Elbette iktisat disiplininde kapitalizmin türlerinin (varieties of capitalism) analiz edildiği oldukça geniş bir literatür (Coates, 2005; Hodgson, 1996; Menz, 2005) bulunabilir. Ancak söz konusu literatür ana akım neoklasik iktisadın kapitalizmi analiz edemiyor olma gerçeğini değiştirmez. Çünkü ilgili literatür, hem kapitalizmin farklı ülkelerde görülme biçimleri üzerinedir ve devletin iktisadi yaşam içindeki yerini tartışır hem de ana akım neoklasik iktisat dışı bir analiz sunar. Örneğin, Fransız Düzenleme Kuramı'ndan Michel Albert (1992) Ren/Alman kapitalizmi ve Amerikan kapitalizmi arasındaki farkın regülasyon politikaları bağlamında geliştiğini, ülkelerdeki çalışma saatlerinin farklı olduğunu ve her iki modelde de piyasa ile dinlerin yerlerinin farklılaştığını belirtir. Ayrıca kapitalizmin türlerini konu alan bu literatür, iktisadi bir analizden daha çok sosyolojik içerikli bir analiz sunar.

Hatta Deirdre McClosykey’e göre (2010: 409) iktisat bilimi, modern dünyayı kuran Sanayi Devrimini ve kapitalizmin ortaya çıkışını da açıklayamamaktadır. Ticaret, yatırım ve teşvikler gibi sadece iktisadi faktörler üzerinden kapitalizmin Kuzey Avrupa'da ortaya çıkışını açıklamak mümkün değildir. Hollanda ve İngiltere'de modern dünyayı kuran "burjuva devrimini”, akı1/sağduyu yanında ölçülülük, adalet, aşk, inanç, umut ve cesaret gibi "erdemler" üzerinden tanımlamak mümkündür. $\mathrm{Bu}$ dönemde insanlar söz konusu erdemler aracılığıyla yeniliğin yaratıcı yıkımını kabul

${ }^{9}$ Söz konusu katışılılılı ilkesinin Karl Polanyi (2000) tarafından 19. yüzyılda gelişen piyasa ekonomisini açıklamak üzere kullanıldığ 1 söylenebilir. Polanyi'ye göre kendi kendini düzenleyen etmişlerdir ve modern dünya bu düşüncelerle ortaya çıkmıştır.

Bu noktada ana akım olarak neoklasik iktisadın hem temel araştırma nesnesinin kapitalist sistem olmadığ hem de ilgili kapitalizmi anlamaktan uzak olduğu açıkça ortaya çıkmaktadır. Ana akım neoklasik iktisat doğa bilimleri tarzında evrensel ve nesnel geçerlilikte bir bilim peşindedir. Yani yaygın kanının aksine "kapitalizm", "sosyalizm", "liberalizm", "mülkiyet" ve "sosyal adalet" gibi kavramların ana akım neoklasik iktisadın standart dilinde yeri yoktur. İlgili kavramların ana akım iktisat içerisindeki yeri ders kitaplarının giriş kısmındadır. Örneğin iktisadın tanımladığı genel dengeye dayalı piyasa işleyişinin temelindeki kapitalizmin teşhisini gerçekleştirmek, iktisadın standart dili içerisinde kalınarak mümkün değildir. Kapitalizm kavramı her durumda ekonomik, sosyal ve politik içeriklidir. Bu nedenle kapitalizm kavramının ana akım iktisadın standart dilinde yeri yoktur (Y1lmaz, 2001/2002: 90). Ana akım iktisadın kapitalizm analizi olarak yapmaya çalıştığı, piyasa dengesinin matematiksel ve teknik bir dille nasıl oluştuğunu göstermektir. Bu nedenle ana akım neoklasik iktisat teorisi, kendi yöntemleriyle yapılan analizde ne bizzat disiplinin ideolojik rolünü ne de analizlerindeki teknik üstünlüğün aynı zamanda kapitalizmi anlamaya yönelik çabaları gölgede bırakmaya yol açtığını görebilir durumdadır (Yılmaz, 2001/2002: 102).

Başka bir deyişle kapitalizmle ilintili kavramlar seti olan "sanayileşmenin", "milliyetçiliğin" ve "emperyalizmin" iktisat yazınında incelendiğini görmek zordur. Kapitalizmin, yapı ve anlam olarak (soyut bir takım "kapital" teorileri dışında) ana akım iktisatta yeri yoktur. Bu nedenle ana akım neoklasik iktisatçıların temel ilgisi bir sistem olarak kapitalizm ve onunla ilişkili kavramlar değildir (Dowd, 2013: 129). Elbette kapital kelimesi kapitalizmin temelinde olan ve anlaşılması için elzem bir kavramdır. Ancak iktisatçılar uzun zamandır kavramın anlamını değiştirmiş ve kavram anlam kaybına uğramıștır. Artık kapital kelimesinin belirli bir üretim tarzı ile herhangi bir bağlantısı yoktur. Maalesef kapital, iktisatçıların ölçmeye çalıştıkları iddialı ampirik araştırma programlarına ilham vermesine rağmen kavramın ne olduğu ve kapitalizmin gelișimi içinde nasıl bir rol aldığı pek bilinmemektedir (Hodgson, 2014).

Hiç şüphesiz iktisatçılar arasında kapitalizm analizi yapan çok sayıda düşünür vardır. Örneğin, Albert O. Hirschman bunlardan biridir. Hirschman (1982; 2013), kapitalizmin (piyasa toplumunun) ortaya çıkışını, Adam Smith, Montesquieu ve James Steuart gibi düşünürlerden yola çıkarak hukuk, felsefe ve ticaret ekseninde geniş çaplı bir analizle ele almaktadır. Ancak iktisat disiplininde Hirschman, ana akım neoklasik iktisatçıdan ziyade politik iktisatçı olarak kabul edilmektedir ve genellikle 1970 sonrası politik iktisatçılar heterodoks iktisatçı olarak anılmaktadırlar. Bu nedenle ana akım neoklasik iktisadın teorik araçlarıyla kapitalizm analizi gerçekleştirmek hayli güçtür. piyasa fikri, tamamen ütopyadır. 19. yüzyılda piyasa, bilinçli devlet müdahalesi sonucu ortaya çıkmıştur. 
İktisat biliminin teknikleşmesi sonucu hem sosyal olanla bağını koparması hem de spekülatif addettiği düşünsel çabalardan uzaklaşması, ana akım neoklasik iktisadı, içinde yaşadığımız kapitalist sistemi analiz edemeyecek ileri matematiksel bir bilime dönüştürmüştür. Ana akım neoklasik iktisat güçlü bir teknik bilime dönüşmüşken ilgili kapitalizm analizini kendi disiplini içinde ürettiği paradigmatik dille herhangi bir sosyal bilim gerçekleştirebilir mi? Bu soruyu farklı bir bağlamda Jürgen Habermas'a başvurarak cevaplamak mümkündür. Habermas'a göre iktisat, politik bilim ve sosyoloji gibi sosyal bilimler içerisinde sadece sosyoloji bir bütün olarak toplumun sorunlarıyla ilişkisini korumuştur. İktisat ve politik bilim, sosyal topluluğun ve kültürün incelenmesini, sosyal bilimlerin temel sorunsallarından ve yaşama evreni paradigmasından kopartmıştır. Dolayısıyla sosyal bilimler içerisinde sosyoloji, rasyonaliteye dayalı felsefi bir dönüşüm gerçekleştirebilecek bir potansiyele sahiptir. Sosyoloji bunu modernizasyon ve rasyonalizasyon temelinde gerçekleştirebilmektedir (Habermas, 2001: 29; Outhwaite, 1994: 70). Habermas'ın bu yaklaşımından yola çıkarak sonraki kısımda sosyolojinin kapitalizmi analiz etme potansiyeli ile sosyoloji ve kapitalizm ilişkisi tartışılacaktır. Çünkü bugün, kapitalist sistem bir bütün olarak toplumun sorunlarının kaynağı olarak görülüyorsa ve sosyoloji bir bütün olarak toplumla bağını koparmamış ve de felsefi kavrayış potansiyeline sahipse, sosyolojinin analiz edilmesi gerekmektedir.

\section{4. İktisat Sosyolojisi ve Modern Kapitalizm}

Günümüz sosyal bilimlerinde akademik standartlaşma içinde Habermas'ın ifade ettiği felsefi dönüşümü gerçekleştirebilecek olan sosyoloji, kapitalizmi temel araştırma nesnesi olarak kabul edip analiz edebilir mi? ${ }^{10} \mathrm{Bu}$ soruyu sosyolojinin bir alt dalı olarak kabul edilen iktisat sosyolojisi özelinde cevaplamak mümkündür. Çünkü iktisat sosyolojisi, Batılı kapitalizmin ortaya çıkışını, gelişimini ve yönelimlerini inceleyerek öne çıkan bir alt disiplindir.

İktisat sosyolojisi, Alman iktisat sosyolojisi (wirtschaftssoziologie) geleneği, Fransız ekonomik sosyoloji (sociologie economique) geleneği ve 1950'lerde Talcot Parsons ve Neil Smelser gibi sosyologların katkıları sonucu şekillenen Amerikan geleneği olmak üzere üç ana kanaldan oluşmaktadır. İktisat sosyolojisinin ilk geleneği olan Alman iktisat sosyolojisi büyük oranda Alman tarihçi okulu ve Weber'in çalışmalarıyla şekillenmiştir. Yaklaşık olarak 1890 ile 1930'lu yıllar arasında Almanya'da görünürlük kazanan bu geleneğe göre ekonomi, doğası gereği tarihsel ve karşılaştırmalıdır. İktisat, kültürel bilimler içerinde incelenmelidir ve yorumlayıcı bir metodoloji kullanmalıdır. Yorumlayıcı veya anlayıcı denilen bu yöntem tercihi Wilhelm Dilthey yoluyla Alman geleneğine katılmıştır. Weber'e göre ise ilk kez Friedrich Gotll'un vurgulaması ile anlama (verstehen) kavramı iktisada dâhil olmuştur. İktisadi kalkınma ve ekonomide devletin rolü, bu geleneğin odaklandığı başlıca iki konudur. Bu iki konu Almanya'nın sanayileşmesi bağlamında öne çıkmıştır. Bu geleneği şekillendiren temel çalışmalar ise Weber, Sombart

10 Kapitalizmin modern sosyal teorinin temel inceleme nesnesi olduğuna ilişkin bkz. Giddens (2013). ve Schumpeter'den gelmiștir. İkinci gelenek, Fransız iktisat sosyolojisidir ve kökleri Saint-Simon'ın "sanayi toplumu" analizine dayanır. Fransız geleneği 20. yüzyılın başında Durkheimci okulla doruğa ulaşır. Alman geleneğiyle benzerlik taşısa da, Alman iktisat sosyolojisi kapitalizm hakkında analiz yaparken Fransız iktisat sosyolojisi, sanayi toplumu hakkında analiz yapar. Ayrıca bu geleneğin Alman geleneğinden bir diğer fark1, Durkheim'in iktisat bilimine doğrudan düşmanlık göstermesidir. Üçüncü gelenek Amerikan iktisat sosyolojisi ise, 1950'li yıllardan sonra varlık göstermiştir. $\mathrm{Bu}$ gelenek, iktisat sosyolojisi yerine daha çok ekonomi ve toplum ikiliğini kullanmayı tercih eder. Amerikan iktisat sosyolojisine Talcot Parsons ve Neil Smelser gibi sosyologların katkısı büyüktür. Söz konusu sosyologların dışında bu geleneğe çok fazla katkı yapan sosyolog yoktur. Örneğin Chicago Okulu, iktisatçılar ve sosyologlar arasında var olan entelektüel iş bölümüne saygı duydukları için bu geleneğe çok fazla katkı yapmamışlardır. Çünkü Chicago'lu sosyologlara göre "iktisadi" problemler iktisatçıların, "sosyal" problemler de sosyologların ilgi alanına girmektedir. Eğer yeni bir çalışma alanı oluşturmak gerekirse bu alan "meslekler sosyolojisi" ve "sanayi sosyolojisi"dir (Swedberg, 1991). Söz konusu üç iktisat sosyolojisi geleneğinden öncelikli olarak Alman iktisat sosyolojisi, kapitalizmi temel araştırma nesnesi seçerek öne çıkmaktadır. Bu gelenek iktisat sosyolojisini felsefi bir temelle ele almaktadır. Bu yönüyle kapitalizmi de felsefi olarak inceleyerek önem kazanmaktadır. Ancak bu gelenek bugün akademik standartlaşmada modern sosyal teori içerisinde kabul edilmektedir.

Ana akım neoklasik iktisat bu geleneğin çok uzağındadır. Ancak iktisat sosyolojisine sadece sosyologlar katk1 yapmamıştır. Ana akım neoklasik iktisada dâhil olmayan iktisatçılardan da katkı gelmiştir. Özellikle Joseph A. Schumpeter Alman iktisat sosyolojisi geleneğine büyük katkılar yapmıştır. Schumpeter kapitalizm analizi gerçekleştiren nadir iktisatçılardan biridir. Schumpeter sadece yaşadığı dönemde kapitalist sistemdeki gelişmeleri anlamaya çalışmaz, aynı zamanda kapitalist sistemin geleceğine dair düşünceler de belirtir. Schumpeter'in düşüncesinde paradoksal bir terim olan "yaratıcı yıkım" ekonomik gelişmede yeniliğin işlevlerini gösterir. Terim bir oksimorondur ve paradoksal bir görünüme sahiptir. Ancak yenilik yeni bir yaşam biçimi yaratır ve eskisini yıkar, ikisi aynı yönde değildir. Yaratıcı yıkım kavramı piyasa ve rekabet hakkında statik ve dinamik olmak üzere ikili çatışma perspektifi sunar. $\mathrm{Bu}$ tez, kapitalizmin çöküşünü kendi başarılarının sonucuna bağlar. Paradoksun püf noktası iktisat sosyolojisi çerçevesinde ekonomik ve ekonomik olmayan alanların etkileşimidir. Bu da kapsamlı bir medeniyet olarak kapitalist sistemin sosyal, politik ve kültürel durumlar içermesidir. ${ }^{11}$ İlgili bağlamda Schumpeter'in zihin ve topluma üç katmanlı ve iki yapılı bir yaklaşımı vardır. Söz konusu yaklaşım bazen ekonomik istatistik ve ekonomik dinamik, bazen ekonomik dinamik ve iktisat sosyolojisi, bazen de zihin ve toplum gibi katmanlar arasındaki boşluk olarak görünür (Shionoya, 2004: 345). Ancak Schumpeter'in kapitalizm analizi, iktisat biliminin kapitalizmi analiz

$11 \mathrm{Bu}$ tespit, kapitalizmin katışıklılık ilkesinin örtük de olsa Schumpeter tarafından kabul edildiği manasına gelmektedir. 
edemiyor iddiasını çürütmemektedir. Çünkü Schumpeter'in çalışmaları ana akım neoklasik iktisatçılar tarafından kabul görmez. Ana akım neoklasik iktisatçılara göre Schumpeter iktisatçı değil, sosyal teorisyendir. Dolayısıyla yaptıkları da iktisat değil, sosyal teorinin bir çeşidi olan sosyal iktisat (social economics) veya iktisat sosyolojisidir (Swedberg, 2015: 217). ${ }^{12}$

İktisatçıların (yeni) iktisat sosyolojisine katkıları, 1970 sonrası yeni kurumsal iktisattan da gelmiştir. Yeni kurumsal iktisat teorisinde mikro iktisat, sosyal davranışları ve sosyal kurumları açıklamak için kullanılır. $\mathrm{Bu}$ yaklaşım iktisat sosyolojisinden daha geniş bir alanda görülür. $\mathrm{Bu}$ yaklaşımda asimetrik bilgi, işlem maliyetleri ve aktör temelli organizasyonel davranış önerilmiştir. $\mathrm{Bu}$ organizasyonel yap1 içinde verimlilik (efficiency) merkezi bir kavramdır (Swedberg, 1991: 267). Özellikle yeni kurumsal iktisatçılardan Douglass C. North ve Robert P. Thomas (2009 [1973]) kurumlar, iktisadi değişim ve performans arasında ilişki kurmuşlardır. İlgili yazarlara göre iktisadi gelişmenin temeli verimliliktir. Verimlilik ise, kurumsal yapılara bağlıdır. Verimli iktisadi organizasyon, büyümenin anahtarıdır. Batının iktisadi yükselişi bu "kurumsal değişime" bağlıdır. Bu yazarlar kapitalist gelişim sürecini yeni kurumsal iktisat teorisi bağlamında yorumlamaktadırlar. ${ }^{13}$ Ancak yaptıkları sınırlı bir kapitalizm tahlilidir ve yeni bir iktisat tarihi okumasıdır. Yeni kurumsal iktisadın kapitalizm tahlili, kurumlar üzerinden Batının iktisadi gelişimini anlama denemesi olarak görülebilir. Buradaki çabaları bütünlüklü bir kapitalizm analizi olarak değerlendirmek yanlış olur. Yeni kurumsal iktisadın kapitalizm tahlili, 1970'li yıllarda tıkanan ve Batının iktisadi gelişimini tam olarak açıklayamayan ana akım iktisat öğretisine kurumlar yoluyla nefes aldırma girişimidir. Burada içinde yaşadığımız çok yönlü kapitalist sistemi anlamaya yönelik çabalar yoktur, bir nevi bu sistemi teorik meşrulaştırma çabaları vardır.

Görüldüğü üzere günümüzde sosyoloji ve özellikle iktisat sosyolojisi disiplininde kabul edilen ancak ele aldıkları konular itibariyle sosyolojinin sınırlarını da aşan Weber ve Schumpeter gibi düşünürlerin içinde yaşadığımız modern dünyayı anlamak için büyük oranda kapitalizm analizinde bulundukları söylenebilir. Bu isimlere Fernand Braudel, Karl Polanyi, Jean Baudrillard gibi düşünürler de eklenebilir. Söz konusu isimlerin herhangi bir sosyal bilim disiplinine dâhil edilmeyecek çapta bir yaklaşım geliştirdiklerini söylemek mümkündür. Sınırlı disipliner söylemler kapitalizm gibi katışıklılık ilkesi üzerinden işleyen büyük sistemi anlamanın önünde engel olmaktadırlar. Ancak sınırlı paradigmatik bir dile sahip olmayan ve kapitalist toplumsal gerçekliğin teorisini yapmaya çalışan politik iktisat, politik felsefe ve bütünleşik sosyal teori bağlamında günümüz kapitalizmini anlamamız mümkün müdür? Çalışmanın bir sonraki kısmında bu sorunun cevabı aranacaktır.

12 Benzer şekilde İkinci Dünya Savaşı sonrası Amerikan kapitalizmini büyük şirket analiziyle ele alan John Kenneth Galbraith da iktisatçı olarak değerlendirilmez. Ana akım iktisatçılara göre Galbraith iktisatçı değil, sosyal teorisyendir (Dunn ve Pressman, 2005: 190). Ana akım iktisatçılar tarafından sosyal teorisyen olarak değerlendirilmenin disiplin içinde pejoratif bir anlam içerdiği unutulmamalıdır.

\section{Politik İktisat, Politik Felsefe ve Bütünleşik Sosyal Teorinin İmkânları}

Dimitris Milonakis ve Ben Fine (2009) iktisadı, tekrar politik iktisat eksenine oturtmaya çabaladıkları çalışmalarında, politik iktisad1, tarihsel ve sosyal yönleri olan politik felsefe ve bütünleşik bir sosyal teori olarak tahayyül etmektedirler. Çağdaş dönemde ise kapitalizm bağlamında dikkate değer politik felsefe ve sosyal teori çalışmaları Slovaj Žižek ve Kojin Karatani gibi düşünürlerce yapılmaktadır. Elbette bu isimlerin dışında kapitalizmi temel araştırma nesnesi olarak ele alan birçok düşünür vardır. Ancak söz konusu düşünürlerin çalışmalarına daha yakından bakıldığında bu düşünürlerin disiplinlerarasılık gibi bir maksatla modern kapitalizmi analiz ettiklerini söylemek güçtür. Bu isimlerin politik felsefe ve sosyal teori ile uğraştıkları öne sürülse de yaptıkları büyük oranda herhangi bir sosyal bilim disiplinine sığmayacak denlidir. Belki bu isimlerin çabalarını modernliğin genel bilimi olarak düşünülen politik felsefe ve sosyal teoriyi de içeren politik iktisat kapsamında düşünmek gerekir. Ancak bu çaptaki politik felsefe ve sosyal teori çalışmaları ile mevcut iktisat bilimini bir araya getirmek de mümkün değildir, zaten ana akım iktisadın mevcut teknik doğası buna müsaade etmemektedir. İktisat, özellikle İkinci Dünya Savaşı sonrası, bu denli çabalardan uzaklaştığı müddetçe bilimselleşeceğini iddia eden bir disiplindir. Bu bakımdan böyle bir vasatta bir önceki bölümde gerçekleştirilen sınırlı disipliner dile yönelik eleştirinin söz konusu düşünürlere getirilmesi pek mümkün gözükmemektedir.

Örneğin Žižek (2019), Lacancı psikanalizden yola çıkararak kapitalist söylemi analiz etmektedir. Ona göre hegemonik ideolojinin koordinatları içinde küresel kapitalizm, genişleyen bir döngüye sahiptir. Psikanalitik deyimle libidinal bir rejim olan kapitalist söylem, tüm geleneksel biçimlerin altını oymaktadır, sınırsız bir kendi kendini yeniden üretme döngüsü olarak görünmektedir. Psikanalitik terimlerle, yasanın üstünlüğünü/hadımını askıya alan libidinal rejimdir bu. Doğulu dinler ve moral sistemlerden (Asya değerlerinden) ekolojiye kadar kapitalist söylem, dünyanın her yerine yaratıcı yıkım özelliğini dayatır. Kapitalist genişleme ve dışsal sınırları arasındaki karşıtlık sahtedir. Kapitalist sisteme içkin olan ve tam da sınırsız genişlemenin motorunu oluşturan sınırı (antagonizmayı) görmezden gelir. Libidinal açıdan kapitalizm psikoz değil, sapkınlık rejimidir; hadımı dışarıda bırakmak veya askıya almak yerine inkâr eder. Žižek için kapitalist sistem herhangi bir uzmanlık alanıyla değil, belirli alanların kesişim noktalarında kalan boşluk kısımlarıyla beraber analiz edilmesi gerekir ve kapitalist sistem ancak bu şekilde anlaşılabilir. $\mathrm{Bu}$ nedenle Žižek'in neredeyse bütün çalışmalarında psikanaliz, politik felsefe ve politik iktisat at başı gider. Žižek, içinde yaşadığımız kapitalist sistemin ancak bu şekilde çözümlenebileceğini söyler ve ilgili teorik

13 İkinci Dünya Savaşı sonrası kapitalizm, iktisadi gelişme ve kurumsal iktisat ilişkisini Gunnar Myrdal'ın çalışmalarında da bulmak mümkündür. Ancak Myrdal da ana akım iktisatçı olarak kabul edilmemektedir. Orijinal kurumsal iktisatçı olarak tanınmaktadır. 
çeşitlenmeye film eleştirilerini de ekleyerek resmi tamamlamaya çalışır.

Bir diğer düşünür Karatani ise (2008; 2017) modern kapitalizmin ulus, sermaye ve devlet üçlüsünden oluştuğunu iddia eder. Bu üçlü yapı içinde kapitalist piyasa ekonomisi en başta gelir. Sermaye, ulus ve devlet hepsi birbirinden farklı olmakla ve her biri kendi ilkeleri üzerinde yükselmekle birlikte, karşılıklı olarak birbirlerini tamamlayacak şekilde bir araya gelir. Üçünden biri gidecek olursa, sistemin tamamı çöker. Bugüne kadar bu sistemi tam olarak kavrayan Hegel'dir. Marx, Hegel'i eleştirerek entelektüel kariyerine başlamıştır ancak o da etiği ihmal etmiştir. İşte Karatani’ye göre (2017) ulus, sermaye ve devlet üçlüsü Kant ve Marx’ın birleştirilmesi ile anlaşılmalıdır. Bunun için Karatani, Kant ve Marx'1 birleştirerek kapitalist sistemi anlayıp aşmaya gayret eder. Kant'tan etik Marx'tan ise kritik/eleştiri kavramını alarak yeni bir teori inşa etmeye çabalar. Bu teori birlikçiliktir. Karatani kapitalist sistemi talan, bölüşüm ve meta olmak üzere üç mübadele biçimi şeklinde ifade eder. Ayrıca dördüncü mübadele biçimi de birliktir. Bir yardımlaşma biçimi olan birlikçilik toplulukta olduğu gibi hem dışlayıcı hem de zorlayıcı değildir. Birlikçilik, toplum kapitalist ekonomiden geçtikten sonra ortaya çıkan etik ve ekonomik bir insani ilişki biçimidir. Birlikçiliğin ilk defa Proudhon tarafından ortaya atıldığı zannedilir. Ancak Karatani için Kant'ın etik teorisi birlikçiliği içermektedir. Zaten Karatani için, Marx'ın komünizm olarak adlanırdığı şey, Kant'ın “amaçlar krallığgı” dediği şeyden çok da farklı değildir. Başka bir ifadeyle, bir kişinin diğerine "asla salt amaca götüren bir araç değil, aynı zamanda hep bir amaç" muamelesi yapacağı bir toplumdur bu. Kant'ın ahlakı bir iyikötü sorunu değil özgürlük (kendiliğinden kendi kaderini belirleme) sorunudur (Karatani, 2017: 23).

Hem Žižek hem de Karatani'nin yaklaşımlarında görüldüğü üzere, sol teorisyenler düşünsel olarak tıkandıkları noktada, felsefeden yardım alıp yeni bir teori inşa ederek kapitalist sistemi aşmaya girişmektedirler. Bu girişim, politik felsefe ve sosyal teoriyi içeren geniş bir politik iktisat olarak düşünülebilir. Bunun Ortodoks bir Marksizm denemesi olmadığı da açıktır. Fakat burada inşa edilen teorideki sorun, günümüzde, Carl Schmitt'in (2016: 70) dediği gibi, iktisadi/teknik düşüncenin politiği boğmasıdır. Artık politik sorunlar yoktur. Yalnızca örgütsel/teknik ve ekonomik/sosyolojik ödevler vardır. Bugün egemen olan ekonomik/teknik zihniyet artık politik bir düşünceyi kavrayamamaktadır. Modern devlet büyük bir fabrikaya dönüşmüştür (Schmitt, 2016). Burada görülen bir diğer sorun alternatif sistem önerisinin kendisindedir. Žižek ve özellikle Karatani örneğinde kapitalizmi anlamak için bir imkân olarak öne çıkan politik felsefe ve sosyal teori bize yeni bir kurtarıc1 politik iktisat sistemi sunmaktadir. Baudrillard'ın (2009: 96) ifade ettiği üzere bu tarz kurtarıcı düşüncelerden uzaklaşmak önemlidir. Çünkü kapitalizme dair bu tarz alternatifler, "diyalektik" söylemin arkasına gizlenerek kapitalist sistemi daha geniş bir çerçeve içine oturtarak yeniden üretmeye mahkûm etmektedir. O zaman, Žižek ve Karatani örneğinde dile gelen politik felsefe ve sosyal teorinin, kapitalizmi anlama imkânını alternatif üretme çabası içinde yok ettiği söylenebilir.

\section{Sonuç}

Modernliğin genel bilimi olarak öne çıkan, politik felsefe ve sosyal teori çabalarını da içeren politik iktisat, herhangi bir disipliner sınırlamaya tabi olmadan kurumlar, sınıf, hukuk, politika ve ekonomi gibi geniş bir inceleme alanına sahiptir. Politik iktisat, ticari ve sanayi kapitalizmi dönemlerinde geliştiği için kendini var eden toplumsal gerçekliği bir bütün olarak analiz etmeye çabalamıştır. Bu nedenle politik iktisat, 17. ve 19. yüzyıllar arasında gelişen toplumun iktisadi temellerini anlamaya çalışan bir sosyal teoridir (Clarke, 1991: 12). Ancak 19. yüzyılın sonlarında fiyatlama sorununu çözmek için fayda değer kavramının öne çıkması ve sosyal bilimler arasında gerçekleşen entelektüel işbölümü kapsamında politik iktisat, iktisada dönüşürken araştırma nesnesini daraltmıştır. Artık iktisat, politik felsefe ve sosyal teori gibi geniş bir alanla ilgilenmek yerine piyasayı ve ilgili piyasadaki fiyatların oluşum sürecini kendine araştırma nesnesi seçerek bilimsel gidişatını keskinleştirmiştir. İkinci Dünya Savaşı sonrası bu bilimsel keskinlik formunu, matematiksel araçlarla daha ileri boyutlara taşıyarak teknik bir bilime dönüşmüştür. Bu nedenle bu çalışmada ana akım iktisat biliminin teorik araçlarıyla içinde yaşadığımız kapitalist sistemi analiz etmenin pek mümkün olmadığı gösterilmeye çalışılmıştır. Matematiksel bir tekniğe dönüşen ana akım iktisat bilimi, politik iktisattan uzaklaştığı için tarihsel ve sosyal olanla bağını kopararak kapitalizmi araştırma nesnesi olmaktan çıkarmış ve böylece kendisi için korunaklı bir bilim alanı oluşturmuştur. Doğa bilimlerine en yakın sosyal bilim olarak güçlü bilimsel kazanımlarına rağmen, katışıklılık ilkesi üzerinden ilerleyen kapitalizmi de anlamaktan uzaklaşmıştır.

Ana akım neoklasik iktisadın inceleme alanı dışında bıraktığı kapitalizm, modern sosyal teori içerisinde konumlanan iktisat sosyolojisinin Alman geleneğinin temel araştırma nesnesi olmuştur. Bu gelenek Weber ve Schumpeter gibi düşünürlerle kapitalizmin çıkışını, gelişimini ve geleceğini incelemeye çabalamıştır. Ancak Weber ve Schumpeter gibi düşünürleri sadece bu gelenek içinde değerlendirmek mümkün değildir. $\mathrm{Bu}$ isimler, bütün Batı düşüncesine yön veren araştırmalarda bulunmuşlardır. $\mathrm{Bu}$ nedenle hem bu isimlerin hem de temel inceleme nesneleri olan kapitalizmin herhangi bir disipliner sınırlamaya tabi tutulmadan ele alınmaları yerinde olur. Sinırlı disipliner paradigmalar kapitalizmi anlamaktan uzaktır. İktisat sosyolojisi gibi disipliner sınırlamaları aşan araştırma çabaları ve politik felsefe ve sosyal teoriyi içeren politik iktisadın olası zindeliği, kapitalizmi anlamak için önem arz etmektedir. Fakat Žižek ve Karatani örneklerinde görüldüğü üzere günümüzde bu çabaları ifade eden yaklaşımların kapitalizme alternatif sistem üretme isteği, kapitalist sistemi tahkim eden birer tecrübeye dönüşmekte ve böylece kapitalizmi anlama imkânı olmaktan da hızlıca uzaklaşmaktadır.

\section{Kaynakça}

Albert, M. (1992). Kapitalizme Karşı Kapitalizm. Cemil Oktay \& Hüsnü Dilli (Çev.). İstanbul: Afa Yayınları.

Aspromourgos, T. (1986). On the Origins of the Term 'Neoclassical'. Cambridge Journal of Economics, 10(3), 265-270. 
Baudrillard, J. (2009). Gösterge Ekonomi Politiği Hakkında Bir Eleştiri. Oğuz Adanır \& Ali Bilbin (Çev.). İstanbul: Boğaziçi Üniversitesi Yayınevi.

Becchio G., \& Leghissa, G. (2017). The Origins of Neoliberalism: Insights from Economics and Philosophy. London: Routledge.

Block, F. (2019). Problems with the Concept of Capitalism in the Social Sciences. EPA: Economy and Space, 51(5), 1166-1177.

Boettke, P. J., Coyne, C. J., Leeson, P. T., \& Sautet, F. (2005). The New Comparative Political Economy. The Review of Austrian Economics, 18(3/4), 281-304.

Bögenhold, D. (2010). From Heterodoxy to Orthodoxy and Vice Versa: Economics and Social Sciences in the Division of Academic Work. The American Journal of Economics and Sociology, 69(5), 1566-1590.

Cardoso, J. L. (2004). Natural Law, Natural History and the Foundations of Political Economy. Davis, J. B., Marciano, A., \& Runde, J., (Eds.), The Elgar Companion to Economics and Philosophy içinde (s. 3-23). Cheltenham: Edward Elgar.

Clarke, S. (1991). Marx, Marginalism and Modern Sociology. London: Macmillan Academic and Professional.

Coates, D. (Ed.). (2005). Varieties of Capitalism, Varieties of Approaches. New York: Palgrave Macmillan.

Colander, D. (2000). The Death of Neoclasical Economics. Journal of the History of Economic Thought, 22(2), $127-143$

Colander, D., Holt, R. P. F., \& Rosser, J. B., (2004). The Changing Face of Mainstream Economics. Review of Political Economy, 16(4), 485-499.

Davis, J. B. (2008). The Turn in Recent Economics and Return of Ortodoxy. Cambridge Journal of Economics, 32(1), 359-366.

Dequech, D. (2007/2008). Neoclassical, Mainstream, Orthodox, and Heterodox Economics. Journal of Post Keynesian Economics, 30(2), 279-302.

Dow, A., Dow, S., \& Hutton, A., (1997). The Scottish Political Economy Tradition and Modern Economics. Scottish Journal of Political Economy, 44(4), 368383.

Dow, S. C. (2008). Plurality in Ortodox and Heterodox Economic. The Journal of Philosophical Economics, 1(2), 73-96.

Dowd, D. (2013). Kapitalizm ve Kapitalizmin Iktisadı: Eleştirel Bir Tarih. Cihan Gerçek (Çev.). İstanbul: Yordam Kitap.

Dunn, S. P., \& Pressman, S., (2005). The Economic Contributions of John Kenneth Galbraith. Review of Political Economy, 17(2), 161-209.

Frey, B., \& Benz, M., (2004). From Imperialism to Inspiration: A Survey of Economics and Psychology. Davis, J. B., Marciano, A., \& Runde, J., (Eds.), The
Elgar companion to Economics and Philosophy içinde (s. 61-83). Cheltenham: Edward Elgar.

Giddens, A. (2013). Kapitalizm ve Modern Sosyal Teori. Ümit Tatlıcan (Çev.). İstanbul: İletişim Yayınları.

Gulbenkian Komisyonu. (2003). Sosyal Bilimleri Açın: Sosyal Bilimlerin Yeniden Yapılanmast Üzerine Rapor. Şirin Tekeli (Çev.). İstanbul: Metis Yayınları.

Habermas, J. (2001). Iletişimsel Eylem Kuramı. Mustafa Tüzel (Çev.). İstanbul: Kabalcı Yayınları.

Hagemann, H. (2011). European Emigres and the 'Americanization' of Economics. European Journal of the History of Economic Thought, 18(5), 643-671.

Hirschman, A. O. (1982). Rival Interpretations of Market Society: Civilizing, Destructive, Or Feeble?. Journal of Economic Literature, 20(4), 1463-1484.

Hirschman, A. O. (2013). The Passions and the Interests: Political Arguments for Capitalism Before its Triumph. Princeton: Princeton University Press.

Hodgson, G. M. (1996). Varieties of Capitalism and Varieties of Economic Theory. Review of International Political Economy, 3(3), 380-433.

Hodgson, G. M. (2014). What is Capital? Economists and Sociologists Have Changed its Meaning: Should It Be Changed Back?. Cambridge Journal of Economics, 38(5), 1063-1086.

Hodgson, G. M. (2015). Conceptualizing Capitalism: A Summary. Competition \& Change, 20(1), 37-52.

Karatani, K. (2008). Transkritik: Kant ve Marx Üzerine. Erkan Ünal (Çev.). İstanbul: Metis Yayınları.

Karatani, K. (2017). Dünya Tarihinin Yapısı: Üretim Tarzlarından Mübadele Tarzlarına. Ali Karatay (Çev.). İstanbul: Metis Yayınları.

Lerner, A. (1972). The Economics and Politics of Consumer Sovereignty. American Economic Review, 62(2), 258-266.

McCloskey, D. (2010). The Bourgeois Dignity: Why Economics Can't Explain the Modern World. Chicago: University of Chicago Press.

Menz, G. (2005). Varieties of Capitalism and Europeanization. Oxford: Oxford University Press.

Mestrovic, S. (2004). Uygar Barbarlı: Bir Postmodern Eleştiri Teorisi. Mehmet Özay (Çev.). İstanbul: Açılım Kitap.

Milonakis, D., \& Fine, B., (2009). From Political Economy to Economics: Method, the Social and the Historical in the Evolution of Economic Theory. London: Routledge.

North, D. C., \& Thomas, R. P., (1973 [2009]). The Rise of the Western World: A New Economic History. Cambridge: Cambridge University Press.

Omori, I. (2003). The 'Scottish Triangle' in the Shaping of Political Economy: David Hume, Sir James Steuart, and Adam Smith. Sakamoto, T., \& Tanaka, H. (Eds.). 
The Rise of Political Economy in the Scottish Enlightenment içinde (s. 103-118). London: Routledge.

Outhwaite, W. (1994). Habermas: A Critical Introduction. Cambridge: Polity Press.

Özel, M. (1994). İktisadi Düşüncenin Laikleșmesi. Özel, M., (Der.), İktisat Risaleleri içinde (s. 7-33). İstanbul: İz Yayıncılık.

Polanyi, K. (2000). Büyük Dönüşüm: Çağımızın Sosyal ve Ekonomik Kökenleri. Ayşe Buğra (Çev.). İstanbul: İletişim Yayınları.

Rousseau, J. J. (2005). Ekonomi Politik. İsmet Birkan (Çev.). Ankara: İmge Kitabevi.

Schmitt, C. (2016). Siyasi Illahiyat: Egemenlik Üzerine Dört Bölüm. A. Emre Zeybekoğlu (Çev.). Ankara: Dost Kitabevi.

Shionoya, Y. (2004). Scope and Method of Schumpeter's Universal Social Science: Economic Sociology,
Instrumentalism, and Rhetoric. Journal of the History of Economic Thought, 26(3), 331-347.

Solow, R. M. (1997). How Did Economics Get That Way and What Way Did It Get?. Daedalus, 126(1), 39-58.

Swedberg, R. (1991). Major Traditions of Economic Sociology. Annual Review of Sociology, 17, 251-276.

Swedberg, R. (2015). Schumpeter and Talcott Parsons. J Evol Econ, 25, 215-222.

Wallerstein, I. (2000). Bildiğimiz Dünyanın Sonu: Yirmi Birinci Yüzyll İçin Sosyal Bilim. Tuncay Birkan (Çev.). İstanbul: Metis Yayınları.

Yılmaz, F. (2001/2002). İktisatta 'Politik'in Doğası. Doğu Batı, 4(17), 87-103.

Yılmaz, F. (2018). Türkiye'de İktisadi Düşüncenin Yayılımı ve Heterodoks İktisadın İmkânları. Bilimevi İktisat, 1(2), 10-26.

Žižek, S. (2019). Kendini Tutamayan Boşluk: IktisadiFelsefi Köşelikler. Barış Engin Aksoy (Çev.). İstanbul: Metis Yayınları. 